\title{
Elongation Factor 2
}

National Cancer Institute

\section{Source}

National Cancer Institute. Elongation Factor 2. NCI Thesaurus. Code C38586.

Elong ation factor 2 ( $858 \mathrm{aa}, \sim 95 \mathrm{kDa}$ ) is encoded by the human EEF2 gene. This protein plays a role in the GTP-dependent ribosomal A-site to P-site translocation of nascent protein chains. 